\title{
Azolla \& Soya Hulls-Substitutes for Urea in Coir Pith Composting Using Pleurotus Sajor Caju
}

\author{
*Radhakrishnan $\mathrm{S}^{1}$, Anita Das Ravindranath ${ }^{2}$, Sarma U S ${ }^{3}$, and Jayakumaran Nair $\mathrm{A}^{4}$
}

\begin{abstract}
Bio composting process is the available means of converting various organic wastes generated from the industry and the agricultural sectors into beneficial products such as biofertilizers and as a soil conditioners. The unique feature of these agricultural wastes are their organic content, $\mathrm{pH}$, and high $\mathrm{C}$ : $\mathrm{N}$ ratio. Coir pith is a biomass residue obtained during the extraction of coir fibre from coconut husk. Accumulation of coir pith leads to an environmental concern and its management is a major problem with all coir industrialists. The high quantum of its production and the difficulties experienced in its disposal have tended to create a major problem of pollution of large areas of land and water in coir fiber extraction units. Therefore, biodegradation of coir pith is an essential requirement to control pollution. Coir pith, even though a problematic waste; it is a potential wealth when it is converted into valuable organic manure by microbial degradation. A method of composting of coir pith with urea has been developed by Coir Board, India using a fungus viz., Pleurotus sajor caju commercially known as Pithplus.

Application of urea releases higher concentration of ammonia in the soil making it more acidic and retards soil natural fertility. Hence an alternative cost effective nitrogen supplement needs to be developed as a substitute to urea for composting of coir pith. The present study aims at the formulation of bio organic manure from coir pith avoiding inorganic urea in the composting. Overall assessment on the physico chemical properties of the biodegraded coir pith leads to the conclusion that a combination of Azolla and Soya hulls (2:1 ratio) was found to be efficient in lignin degradation and contribute to novel changes in coir pith
\end{abstract}

Key words: Coir pith, Azolla, Soya hulls, Pleurotus sajor caju, Composting, Solid state fermentation.

\footnotetext{
${ }^{1}$ Scientific Assistant, Department of Microbiology, Central Coir Research Institute (Coir Board), Alleppey, Kerala, India. Email: rkharipad@gmail.com

${ }^{2}$ Senior Scientific Officer, Department of Microbiology, Central Coir Research Institute (Coir Board), Alleppey, Kerala, India. Email: anitadas30@gmail.com

${ }^{3}$ Director, Central Coir Research Institute (Coir Board), Alleppey, Kerala, India. Email: uss2000@yahoo.com

${ }^{4}$ Sel. Grade Lecturer, Department of Biotechnology, Kariavattom, University of Kerala, Thiruvananthapuram, Kerala, India. Email: jekksnair@gmail.com
} 


\section{Introduction}

Coir pith is a lignocellulosic biomass which tends to accumulate in the environment forming hillocks due to the presence of a very high percentage of lignin and cellulose (Table 1). Lignin polymers are major obstacle to the efficient utilization of lignocelluloses materials in a wide range of industrial processes. Coir pith hillocks during the course of time turn out to be an ecologically unfavorable environment leaching out toxic phenolics into the natural water bodies which are harmful to aquatic life. Lignin in the coir pith has to be degraded so that it can be used as a good base material for application as a manure in agricultural fields. Direct application of coir pith results in reduction of soil microbial population and immobilize soil available nitrogen. Therefore biodegradation of coir pith is essential to control the pollution caused by its accumulation (Warrier and Moudil, 1947).

Several experimental studies have been conducted on biodegradation of coir pith using combinations of fungi, bacteria, actinomycetes etc which have yielded encouraging results. Composting is the biological conversion of waste material, under controlled conditions, into a hygienic, humus rich, and relatively bio-stable product that conditions soil and nourishes plants. A process of composting has been standardized by Central Coir Research Institute (Coir Board) for preparation of organic manure / fertilizer out of coir pith using urea as nitrogen supplement The manure thus obtained is rich in nitrogen $(1.26 \%)$, phosphorous $(0.06 \%)$ and potassium $(1.20 \%)$ which is essential for plant growth (Venkitaswami, 2003). An exclusively novel method for accelerating the composting of coir pith heaps lying on road sides was also developed at CCRI (Ghosh et al., 2007). Through this technology, the composting of coir pith could be achieved within 21 days and the compost thus produced showed an increased percentage of nitrogen $(1.24 \%)$, phosphorous $(0.055 \%)$ and potassium $(1.16 \%)$ with reduced $\mathrm{C}: \mathrm{N}$ ratio of 20:1, pH of about 6.8 and Electrical Conductivity of 0.23 millimhos / $\mathrm{cm}$ making the compost as a desirable organic manure. The principal change brought about in coir pith during composting is the breakdown of lignin which forms the chief constituent $(32.15 \%)$ in it.

Although composting alleviates the problem of pollution by the accumulation of coir pith, urea which is being used as nitrogen source has some disadvantages. Application of urea for composting of coir pith exerts higher concentration of ammonia in the soil making it even acidic and retards soil natural fertility. High concentration of urea shows burn potential that will kill the plant roots. To overcome these disadvantages, an alternative cost effective nitrogen supplement needs to be developed as a substitute for urea for composting of coir pith.

Experimental trials were designed in combination with different biological sources in varying proportions with Pleurotus sajor caju so as to develop an alternative to urea for composting of coir pith The selected natural components viz., Soya hulls and Azolla are rich sources of nitrogen and are cheap, readily available in market as and when required. Azolla contain $5.71 \%$ of nitrogen, followed by Soya hulls, which is the husk of Soya bean seed with $3.82 \%$ nitrogen content. To determine the rate of degradation of lignin in coir pith, mushroom cultures were maintained on solid substrate (sorghum) and incubated for 15 days. Further the mushroom used in the present study was inoculated and proliferated on coir pith for thirty days to ensure degradation of lignocelluloses. This paper evaluates the potential of use of Azolla and Soya hulls in coir pith as a substitute for nitrogen during its biodegradation by Pleurotus sajor caju.

\section{Materials and Methods}

\section{Culture Inoculums}

The white rot Basidiomycetes, Pleurotus sajor caju was collected from Central Coir Research Institute (Coir Board), Alleppey, Kerala. The culture was maintained on Potato Dextrose Agar slants, stored at $4^{\circ} \mathrm{C}$ and sub cultured once a month. It was mass cultured on sterilized media consisting of sorghum mixed with $0.2 \%$ calcium carbonate as carbon source in polythene bags. Fully grown packets (400 gms) after 15 days of incubation were used for 
carrying out the experimental study on biodegradation of coir pith. Azolla is a small aquatic floating fern, which contains an endosymbiotic microbial community living in the dorsal lobe cavity of the leaves and this association was capable of nitrogen fixation. In many countries this has been extensively used as green manure for long term soil fertility (Fig 1 A). Soybean seed coats, or hulls, represent about 8 to $10 \%$ of the weight of soybean grain used as the primary dietary ingredient for cattle feed (Fig $1 \mathrm{~B})$.

Figure 1. Biological nitrogen supplements

\section{A. Azolla B. Soya hulls}

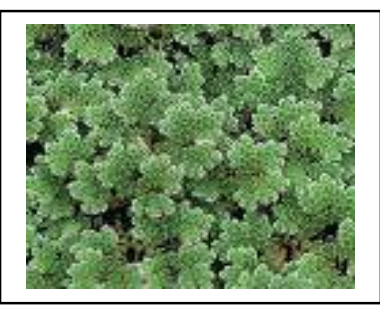

A

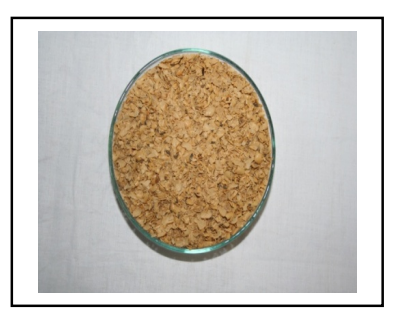

B

\section{Coir pith and biological supplements}

Coir pith used for carrying out this experiment was collected from a coir defibring unit at Kattukada, Cherthala in Alleppey District of Kerala. The biological nitrogen supplements viz., Azolla was collected from a nearby nursery and Soya hulls from Madurai, Tamil Nadu.

\section{Culture Conditions}

Experiment on biodegradation was carried out by laying coir pith heaps in an open shady place. Coir pith was mounted in $5 \mathrm{~kg}$ heaps in triplicate and was substituted with 5\%, 10\%, $15 \%, 20 \%$ and $25 \%$ of biological supplements viz Azolla and Soya hulls separately and in combination to stimulate the production of extra cellular enzymes. An uninoculated coir pith heap was maintained as control for comparison. The experimental coir pith heaps were allowed to decompose for thirty days. Samples have been drawn periodically from the experimental heaps at regular intervals of $5,10,15,20,25$ and 30 days of composting and analyzed for the biodegradation by studying the physicochemical parameters. The Nitrogen, Phosphorous,
Potassium, (NPK) content and $\mathrm{C}$ : $\mathrm{N}$ ratio of biodegraded coir pith was analyzed as per AOAC methods. The properties viz $\mathrm{pH}$, Electrical Conductivity, Salinity of coir pith were also tested at regular intervals., The rate of coir pith degradation was assessed by estimating the percentage of lignin reduction in the samples drawn by Klason method. In order to assess the activity of ligninolytic enzymes viz Lignin peroxidases (LiP) and Manganese peroxidases $(\mathrm{MnP})$ degrading lignin during coir pith composting was also studied using standard enzyme assays.

\section{Enzyme Assay}

Samples of composted coir pith were drawn from the experimental heaps and each sample treated with $25 \mathrm{ml}$ of acetate buffer $(0.1 \mathrm{M})$. The sample was then homogenized using a magnetic stirrer at $4{ }^{\circ} \mathrm{C}$. and centrifuged at $8000 \mathrm{rpm}$ for 10 minutes at refrigeration temperature. The supernatant was analyzed for enzyme activity spectrophotometerically using Hitachi UV-Vis. Spectrophotometer. The change in the absorbance at $431 \mathrm{~nm}$ was observed at intervals of five minutes. A blank was kept as control simultaneously (Worthington CE, 1988).

\section{Assay of lignin peroxide (Li P)}

The reaction mixture containing $2 \mathrm{mM}$ Veratryl alcohol, $0.4 \mathrm{mM} \mathrm{H}_{2} \mathrm{O}_{2}$ and $50 \mathrm{mM}$ tartaric acid was prepared and added to the enzyme extract. The change in absorbance was read at $431 \mathrm{~nm}$. One unit of enzyme activity is defined as the quantity of enzyme required for the formation of $1 \mu \mathrm{M}$ of Veratryl aldehyde per minute.

\section{Assay of manganese peroxide (Mn P)}

A reaction mixture $(50 \mathrm{mM}$ sodium tartrate buffer (pH-4.5), $0.2 \mathrm{mM} \mathrm{MnSO}_{4}, 0.1$ $\mathrm{mM} \mathrm{H} \mathrm{O}_{2} \mathrm{O}_{2}$ and $0.0025 \%$ phenol red) was added to the enzyme extract and the change in absorbance was read at $431 \mathrm{~nm}$. One unit of enzyme activity is defined as the amount of enzyme required for 0.1 O.D change at $431 \mathrm{~nm}$ $\min ^{-1}$. 


\section{Results and Discussion}

It has been observed that partial substitution studies of carbon and nitrogen with vegetative sources could result in the vigorous growth of the mushroom accelerating the rate of lignin degradation leading to an increase in the nitrogen, phosphorous and potassium content in coir pith. The chemical composition of unretted and retted coir pith was analyzed and the results are furnished in Table 1.

Table 1. Chemical composition and physical properties of coir pith

\begin{tabular}{|l|l|c|c|}
\hline $\begin{array}{l}\text { SI } \\
\text { No }\end{array}$ & \multicolumn{1}{|c|}{ Constituents } & $\begin{array}{c}\text { Unretted } \\
\text { coir pith }\end{array}$ & $\begin{array}{c}\text { Retted } \\
\text { coir pith }\end{array}$ \\
\hline 1 & Lignin (\%) & 32.15 & 29 \\
\hline 2. & Cellulose (\%) & 26.40 & 25.10 \\
\hline 3 & Organic Carbon (\%) & 29.5 & 29.0 \\
\hline 4 & Nitrogen (\%) & 0.24 & 0.26 \\
\hline 5. & Phosphorous (\%) & 0.01 & 0.01 \\
\hline 6. & Potassium (\%) & 0.71 & 0.76 \\
\hline 7 & pH & $5.4-5.8$ & $5.6-6$ \\
\hline 8 & EC (millimhos/cm) & $0.8-1.2$ & $0.3-0.6$ \\
\hline 9 & Salinity (ppt) & 1 & $2-4$ \\
\hline 10 & $\begin{array}{l}\text { CEC (Meq / 100 g } \\
\text { of sample) }\end{array}$ & $15-20$ & $20-25$ \\
\hline
\end{tabular}

Application of Azolla as nitrogen source to coir pith resulted in an enhancement of nitrogen to $0.99 \%$, phosphorous to $0.45 \%$ and potassium to $1.04 \%$. Addition of Soya hulls, another natural supplement exhibited comparatively reduced values of NPK viz $0.71 \%, 0.39 \%$ and $0.99 \%$ respectively. Of the different combination trials on coir pith conducted, incorporation of Azolla, and Soya hulls $(2: 1)$ was observed to enhance the NPK in biodegraded pith. The addition of Azolla and Soya hulls (2:1) has exhibited a maximum nitrogen content of $1.18 \%$ compared to the control of $0.26 \%$ in raw coir pith in a period of 30 days. The same dosage of Urea, an inorganic chemical nitrogen fertilizer used in composting exhibited an increase of $1.26 \%$ of nitrogen in coir pith. Other essential elements needed for the growth of plants viz., phosphorous and potassium were also observed to be $0.0519 \%$ and $1.09 \%$ in composted coir pith. (Fig 2).
A significant finding from the foregoing studies reveals that coir pith compost prepared by the addition of urea resulted in yielding $1.26 \%$ of nitrogen, $0.06 \%$ of phosphorous and $1.20 \%$ of potassium whereas the new combination of biological sources resulted in enrichment in NPK level to $1.18 \%, 0.051 \%$ and 1.09 respectively (Fig 3). Even though the values for NPK are comparatively less in composted coir pith, Urea - the artificial fertilizer could be substituted by addition of Azolla and Soya hulls and the technology is ecofriendly and cost effective. Hence the new combination of biological sources formulated in the present study is significant.

The white rot fungi occur naturally as degraders of lignin in fallen trees, ground litter and these organisms have evolved a wide range of nonspecific enzymatic oxidative systems. In natural substrate, co-substrates are obtained by enzymatic polysaccharides [Pandey and Radhakrishnan. 1993]. An excellent review of the decomposition of lignin by wood rotting fungi has been presented by Higuchi [1980]. Studies conducted by Moriya et al. (2001) reveal that extra cellular phenol oxidases produced by the white rot fungi can decompose lignin efficiently during composting.

An important finding from the foregoing studies reveals the fact that composting of coir pith supplemented by combinations of Azolla and Soya hulls $(2: 1)$ result in a steep decrease in lignin content $(10.15 \%)$ from the control value of $32.15 \%$ (Fig 4). Addition of Soya hulls and Azolla separately on coir pith resulted in decreased lignin content of $18.63 \%$ and $14.2 \%$ as compared to the control value of $32.15 \%$ which substantiate the findings of Shashirekha and Rajarethinam (2007) of $42 \%$ volume reduction in coir pith during composting. This could also be related to the findings of Garcia et al. (1980) who reported that white rot fungi are known to have evolved complex enzymatic machinery to degrade lignin, produce extracellullar polyphenols oxidases particularly Lignin peroxidase (LiP), Manganese peroxidase $(\mathrm{MnP})$ and laccases, which are highly effective in depolymerisation of lignin in coir pith. The LiP catalyzes the oxidation of non-phenolic 
Figure 2. Graphical representation of increasing trend of NPK in coir pith degraded with Soya hulls and Azolla separately; 1a \& 1b Nitrogen, 2a \& 2b - Phosphorous, and 3a \& 3bPotassium

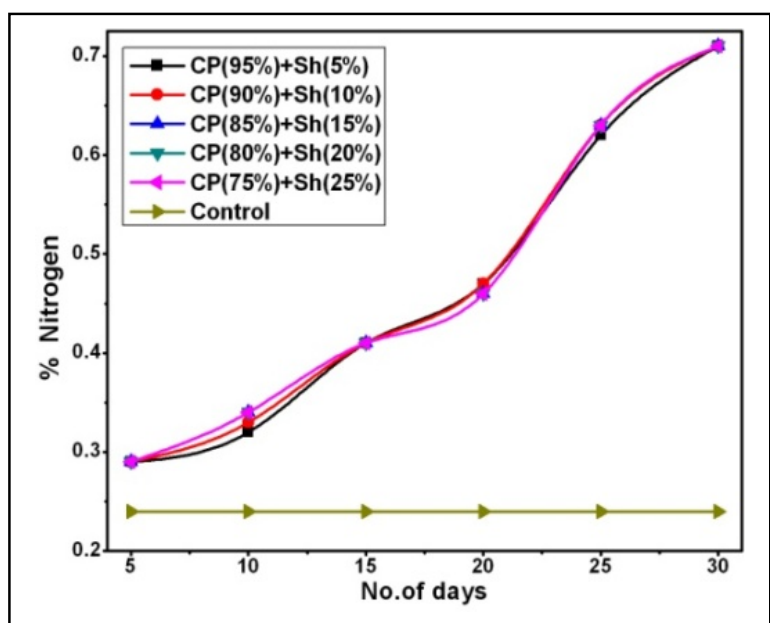

1a

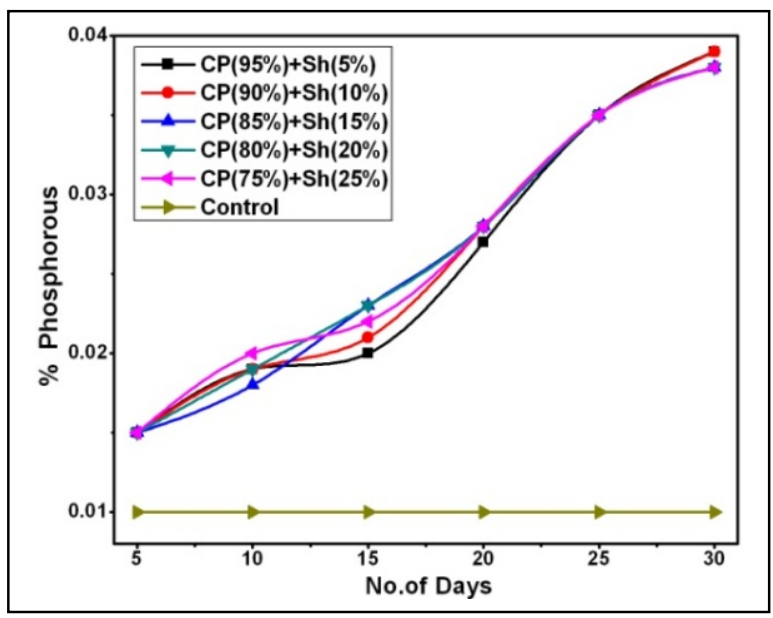

$2 \mathrm{a}$

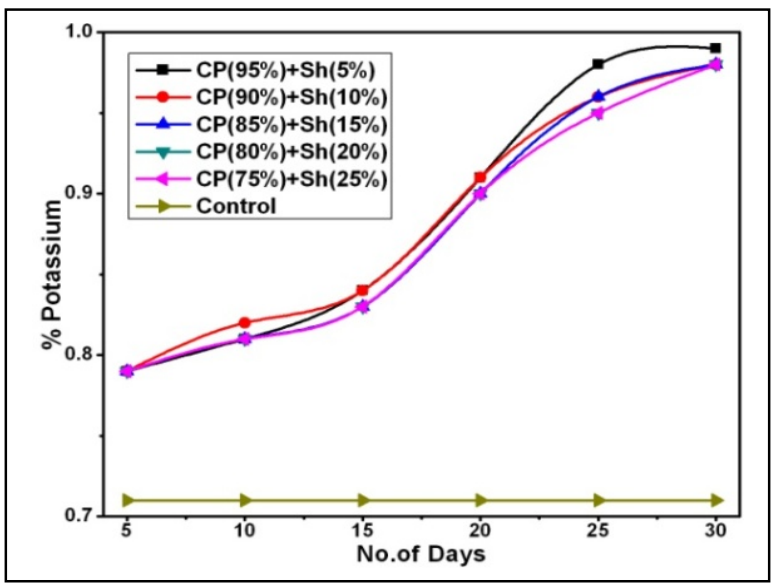

$3 \mathrm{a}$

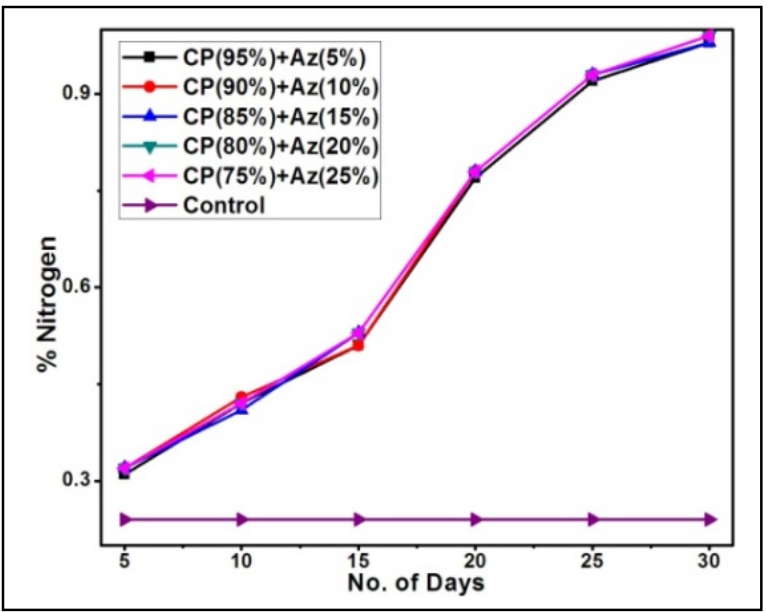

$1 \mathrm{~b}$

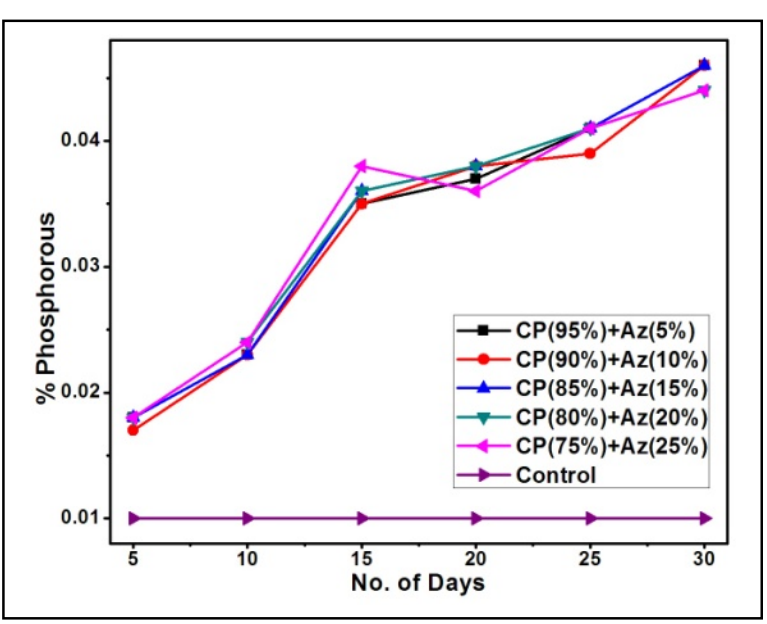

$2 b$

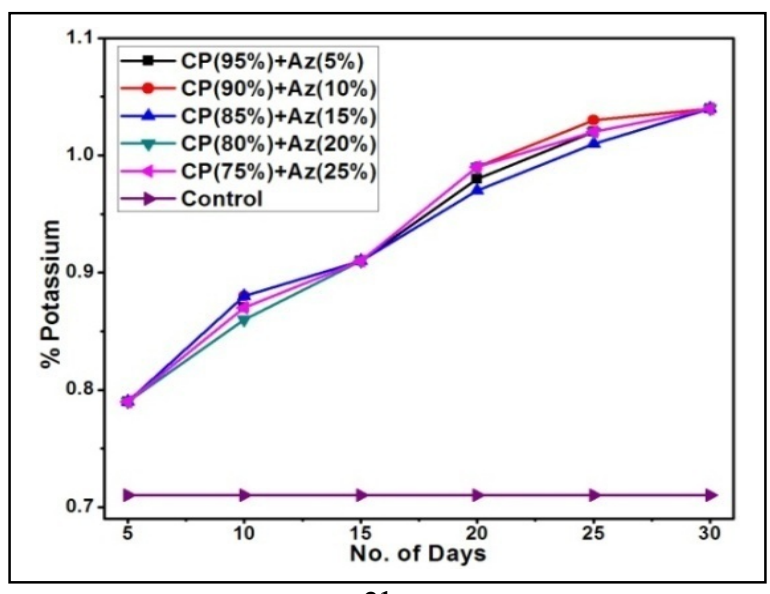

$3 b$ 
Figure 3. Graphical representation of enhancement in NPK in coir pith degraded with biological supplements and $P$. sajor caju

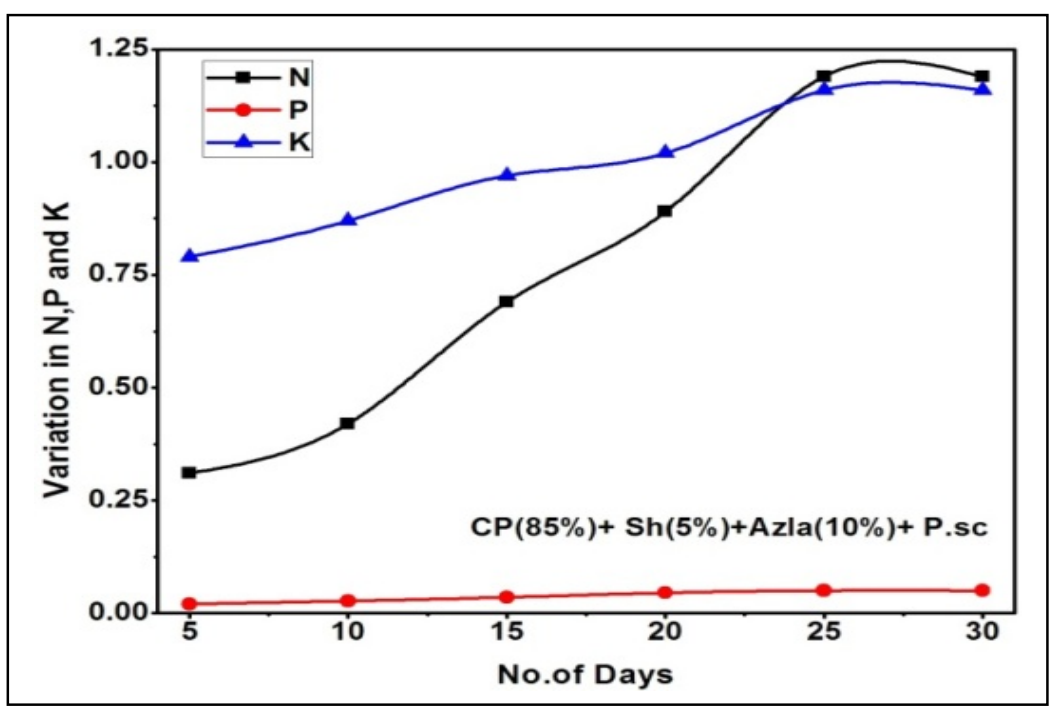

Figure 4. Graphical representation of decreasing trend of lignin content in coir pith during composting; a-Soya hulls, b-Azolla, c-Combination of Azolla \& Soya hulls (2:1)

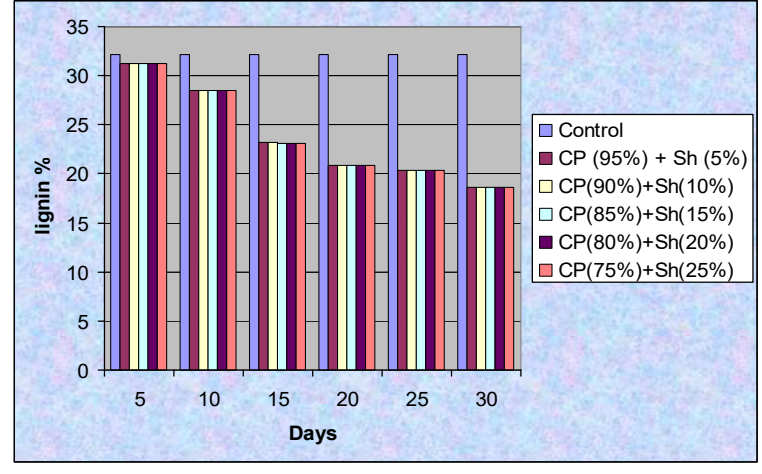

$\mathbf{a}$

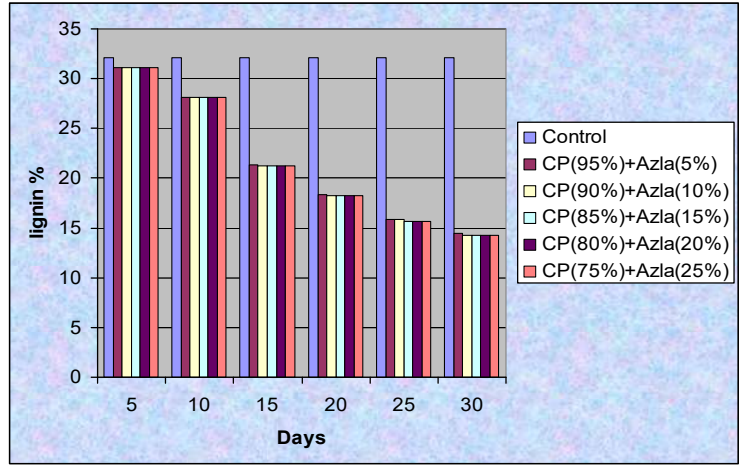

b

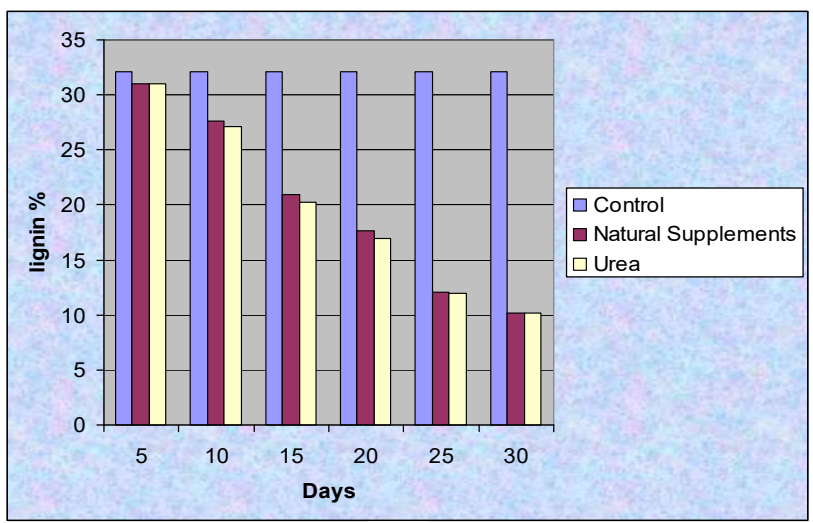


aromatic substrates where as $\mathrm{MnP}$ catalyzes the oxidation of $\mathrm{Mn}^{2+}$ to $\mathrm{Mn}^{3+}$ (Manganous to manganic), which in turn oxidizes many phenolic substrates (Akin et al, 1995). Hydrogen peroxide is required for the activity of these enzymes.

The colonization of mushroom cause biochemical changes in pith by utilizing cellulose, hemicellulose and lignin that lead to variations in nutrient status as reported by Wood (1979) and Moorthy (1981). Rajarathinam and Zakia (1998) and De Bertoldi et al. (1987) tested the four strains of Pleurotus for the degradation of lignocellulose and $P$. sajor caju showed maximum activities of polysaccharide degrading enzymes which could be correlated to weight loss and reduction in lignin content. In the present study it was observed that Pleurotus sajor caju showed the lignin degradation capability with the production of requisite enzymes. Present studies on assaying the activity of ligninolytic enzymes viz., lignin peroxidase and manganese peroxidase could confirm the activity of the enzymes at regular intervals. The maximum enzyme activity was observed in the coir pith heap in a period of 15 to 25 days of inoculation of the mushroom in biological with natural sources of Azolla \& Soya hulls as well as Urea. Further it could be confirmed that the maximum activity of LiP was 16.25 $\mathrm{Uml}^{-1}$ and $\mathrm{MnP}$ was $20.2 \mathrm{U} \mathrm{ml}^{-1}$ on the twentieth day of inoculation with $P$. sajor caju on coir pith (Fig. 5). Thus it is clear that fungal proliferation on coir pith leads to a reduction in organic carbon and lignin content that commenced steadily from the fifth day of inoculation, attained a maximum between fifteenth and twenty fourth day and there after decreased slowly to the minimum. This led to the reduction in lignin content from $32.15 \%$ to $10.15 \%$ in a period of 25 to 30 days.

The present study also confirms the earlier findings of Moorthy (1981) who stated that the $\mathrm{pH}$ remained high until the end of composting process possibly (30 days) due to progressive utilization of organic substrates and increase in the mineral constituents of waste. The raw coir pith with a $\mathrm{pH}$ value of 5.4 shows an increase during composting and raises a neutral value of 6.9 in composted coir pith. Investigation also reveals that incorporation of Azolla and Soya hulls resulted in lowering of EC to 0.21 millimhos/ $\mathrm{cm}$ in biodegraded coir pith compared to the control value of 1.3 millimhos/ $\mathrm{cm}$. The high conductivity indicated in raw coir pith could be attributed to the presence of polyphenols and tannins, which could be reduced by composting with Pleurotus sajor caju. Experimental results also showed a decreasing trend in salinity during composting to a tolerable limit of $0-1$ ppt from 5 ppt as in raw coir pith by frequent sprinkling of water for maintenance of moisture on composting heaps.

Even though coir pith is enriched with micronutrients and possesses water retention properties which could be exploited for agricultural use, farmers hesitate using it mainly due to wider $\mathrm{C}$ : $\mathrm{N}$ ratio, presence of tannin related phenolic compounds and high lignin content (Kadalli and Suseela, 2002). Mandhare et al. (2003) reported that the C: $\mathrm{N}$ ratio of different agro-residues after cultivation of different Pleurotus sp shows significant reduction. Bisaria et al. (1987) reported that loss in weight of substrate might be due to loss of carbon in the form of carbon dioxide by respiratory activity of $P$. sajor caju during its growth. Shetty and Moorthy (1981) reported that the optimum value of $\mathrm{C}: \mathrm{N}$ ratio for plant growth should be below 30:1. Ghosh et al. (2007) suggested that the composted coir pith prepared by the conventional method using urea had exhibited a reduced carbon: nitrogen $(\mathrm{C}: \mathrm{N}$ ratio) from the control value of 112:1 in raw coir pith. The values for carbon and nitrogen obtained from the present study for composting of coir pith with combination of Azolla and Soya hulls also result in reduced C: $\mathrm{N}$ ratio of 20:1 which is in accordance with the earlier findings of Ghosh (Fig. 6).

The study on the reduction of phenol content during composting was carried out using extract collected by soaking raw coir pith and biodegraded coir pith in water. The resulting sample solutions were filtered to remove high molecular weight contaminants. $20 \mu 1$ of the sample extract was studied using a HPLC system (Shimadzu LC 8A) equipped with a bond $\mathrm{C} 18$ column. Observations revealed the result for the reduction of phenols by almost 
Figure 5. Graphical representation of ligninolytic enzyme production by $P$. sajor caju using coir pith as the substrate; A-Composting using biological sources, BComposting using Urea

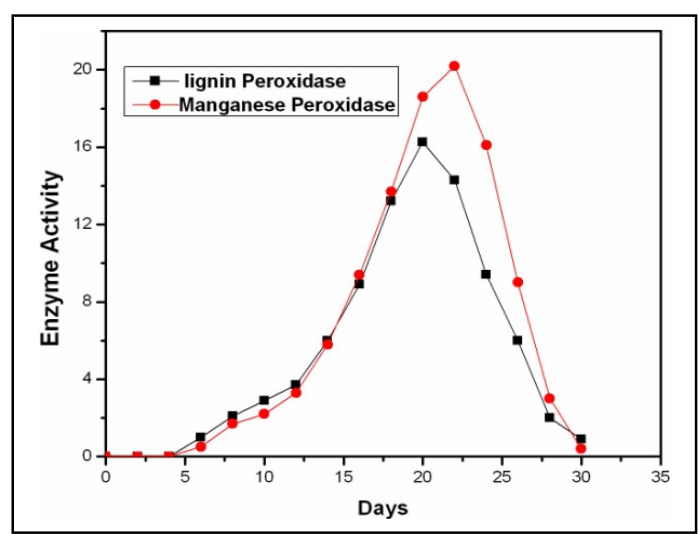

A

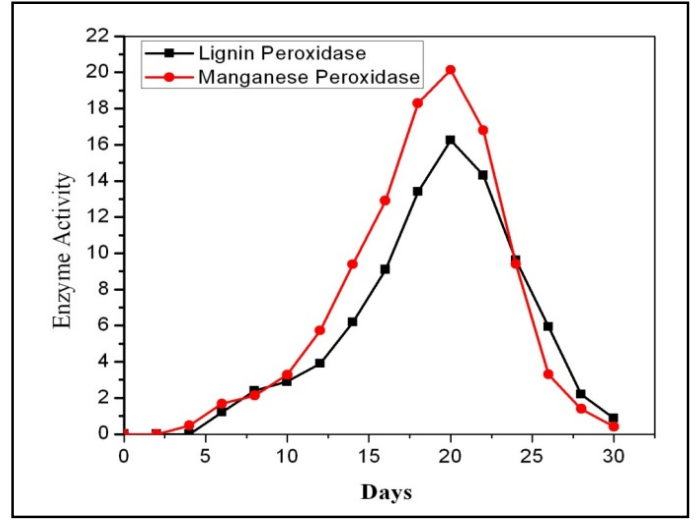

B

Figure 6. Graphical representation of decreasing of trend of $\mathrm{C}$ : $\mathrm{N}$ ratio in composting of coir pith in combination with biological supplements and urea; ABiological supplements, B-Urea

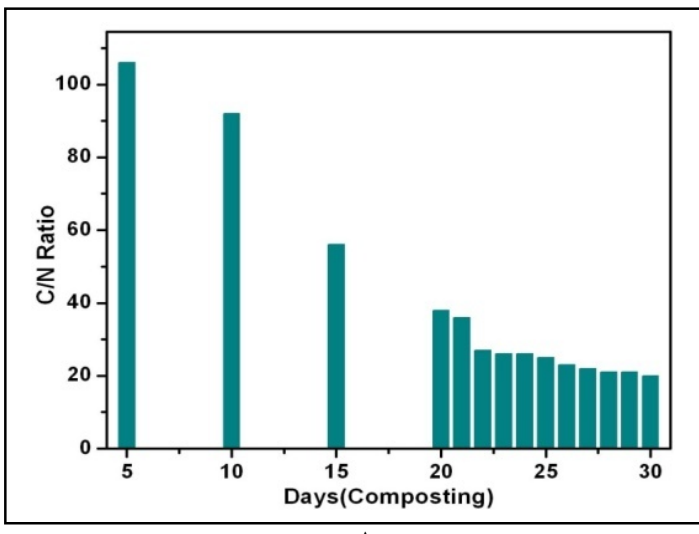

A

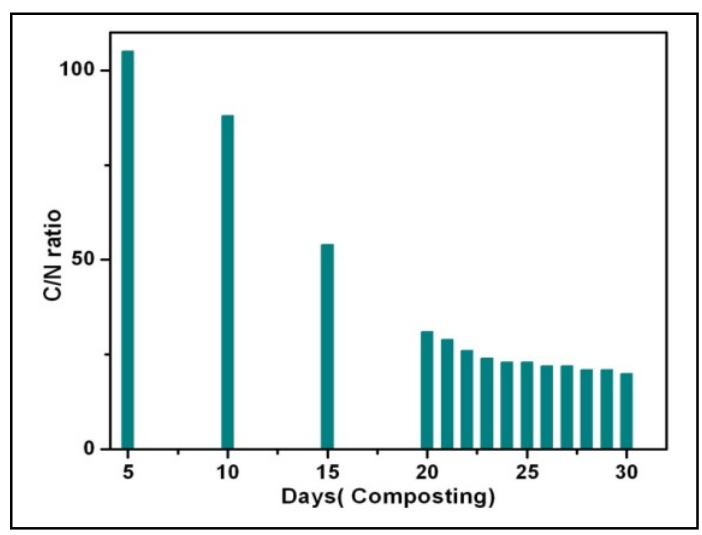

B

Figure 7. Graphical representation of reduction in phenol content in raw coir pith and biodegraded pith; A-Raw coir pith, B-Biodegraded coir pith

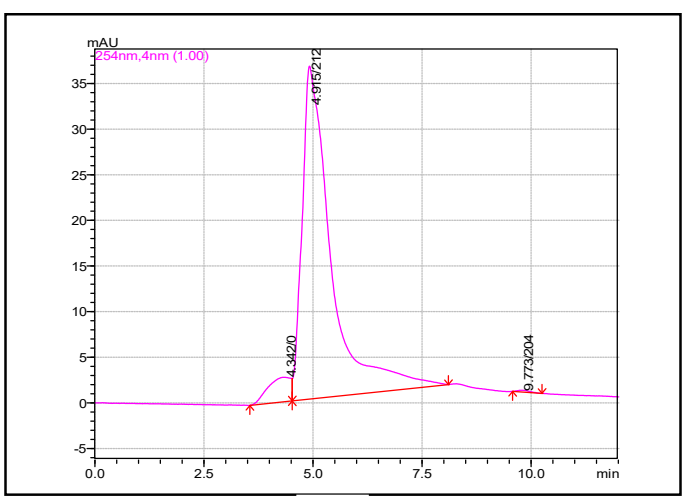

A

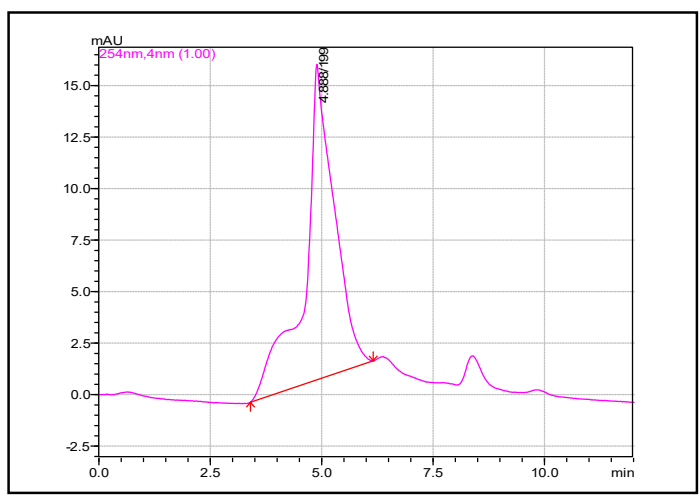

B 
about $50 \%$ as represented by the peak heights (Fig. 7).

Arora et al. (2002) reported that the biodegradation process observed in most mushroom species leads to the reduction in lignin while the other components in coir pith are unchanged. However, the present study made a different observation that apart from the reduction in lignin content, there is also variation in the nutrient status which is important in enhancing the manorial / fertilizer properties of coir pith. Coir pith, both in raw as well as in the composted forms, is gaining increased popularity in developed countries for soil conditioning and in horticulture. The present study confirms that combinations of biological supplements and Pleurotus sajor caju to have the capacity to degrade lignin to a greater extent resulting in the formation of compost. Even though the values for NPK in biologically degraded coir pith are less, composting could be achieved during the same period even in absence of Urea by this cost effective ecofriendly technology. The economics of the process is worked out to be $50 \%$ less than the conventional process of composting using Urea. Thus Urea could be substituted with natural supplements like Azolla and Soya hulls (2:1) which have potential as nitrogen source for composting coir pith.

\section{Conclusion}

Microbes that are the natural components of soil and water environments are potential agents for the biological degradation of waste which tends to accumulate in the ecosystem. Coir fibre extraction leads to the accumulation of coir pith which causes environmental pollution. Therefore biodegradation of coir pith is essential to control the pollution caused by its accumulation. The conventional process of coir pith composting using urea has been observed to be efficient in lignin degradation but has some disadvantages. The present study leads to the conclusion that combination of Azolla and Soya hulls $(2: 1)$ was found to be an alternative and cost effective substitute to urea for ligninolytic degradation of coir pith for solving the problem of environmental pollution.

\section{Acknowledgements}

Authors are thankful to Shri.V.S.Vijayaraghavan, Ex.MP, Hon. Chairman, Coir Board for his valuable support.

\section{References}

Akin, D.E.,Rigsby, L.L. and Sethuraman, A. (1995) Alternations in the structure, and biodegradation of grass lignocelluloses treated with white rot fungi Ceriporiopsis subvermispord and Cyathus stercorius. Appl. Environ. Microbiol. 61: 1591-1598

Arora, D.S., Chander, M. and Gilli, P.K. (2002) Involvement of lignin peroxidase, manganese peroxidase and laccase in the degradation and selective ligninolysis of wheat straw. Int. Bioterior. Biodegrad. 50:115-120.

Bisaria, R., Madan, M. and Bisaria, V.S. (1987) Mineral content of the mushroom $P$. sajor caju cultivated on different agro residues. Mush. J. Trop. 7: 53-60.

De Bertoldi, M., Ferranti, M.P., L'Hermite, P. and Zucconi, F. (1987) Compost production, Quality and Use. Elsevier Applied Science, London, p.853.

Garcia-Martinez, D.V., Shinmyo, Madia, A. and Deman, A. L. (1980) Studies on cellulose production by Clostridium thermocellum. Europ. J. Appl. Microbiol. Biotechnol. 9: 189-197.

Ghosh, P.K., Sarma, U.S., Ravindranath, A.D., Radhakrishnan, S. and Prasenjeet Ghosh (2007) A Novel Method for Accelerated Composting of Coir Pith. Energy Fuels. 21 (2).

Higuchi, T. (1980) Lignin Biodegradation: Microbiology, Chemistry and Potential Applications. Eds T.K.Kirk.T.Higuchi and Hou-Min Chang.CRC Press, Boca Raton, Florida, p.1. 
Kadalli, G.G. and Suseela Devi, L. (2002) Evaluation of enriched coir dust compost for integrated nutrient management system. Dept of Soil Science and Agril. Chemistry, University of Agril. Sciences, GKVK, Bangalore

Mandhare, V.K., Suryawanshi, A.A., Jadav, V.T. and Patil, H.B. (2003) Biochemical changes in different agrowastes due to cultivation of Pleurotus spp. Madras Agr.J; 289-291.

Moriya, O., Yoshimasa, M., Toru, J. and Toshiaki, K. (2001) Lignin degradation and roles of white rot fungi. Study on an efficient symbiotic system in fungus growing termites and its application to bioremediation. Riken Review. 42: 39-42.

Moorthy, K.V. (1981) Microbial and chemical studies on the cultivation of $P$. sajor caju (Fr.) Singer, M. Sc Thesis, University of Agri. Sciences, Bangalore.

Pandey, A and Radhakrishnan, S (1993). The Production of Glucoamylase by Aspergillus niger NCIM 1245. Process Biochemistry 28,305-309

Rajarathinam, S. and Zakia, B. (1998) Biodegradative and biosynthetic capabilities of mushrooms: Present and future strategies. Critical Reviews of Biotechnology. 18(2): 91-236.
Shashirekha, M.N. and Rajarathinam, S. (2007) Bioconversion and biotransformation of coir pith for economic production of Pleurotus florida. Chemical and biochemical changes in coir pith during the mushroom growth and fructification World J. Microbiol Biotechnol. 23: $1107-$ 1114

Shetty, K.S. and Moorthy, K.V. (1981) Possibility of protein enrichment of straw by mushroom P. sajor caju. In: Recycling (ed. M.S. Karla), Punjab Agri.Univ.Ludhiana, 63-67.

Venkatasami, R. (2003), Integrated nutrient management in coconut with composted coir pith. Madras Agric. J., 90 (1-3):54-56 are added as Annexure- 2

Warrier, N.S. and Moudil, K.L. (1947) 'Retting of coconut husk'.J.Scient.Ind.Res.6: 114116.

Wood, D.A. (1979) Degradation of composted straw by the edible mushroom. $A$. bisporous. Enzyme activities with mycelia growth and fruit body formation (Ed. Grass word, E) 95-104.

Worthington, C.E. (1988) Worthington Enzyme Manual, pp. 76-79, Worthington biochemical Corporation, Freehold, NJ. 